\title{
SMOKING HABITS AND ATTITUDES IN STUDENTS OF THE THIRD FACULTY OF MEDICINE OF CHARLES UNIVERSITY IN PRAGUE
}

\author{
Dagmar Schneidrová1, Tereza Kopřivová Herotová', Magdaléna Šustková2, Viktor Hynčica ${ }^{1}$ \\ ${ }^{1}$ Department of Child and Youth Health, Third Faculty of Medicine, Charles University, Prague, Czech Republic \\ ${ }^{2}$ Department of Pharmacology, Third Faculty of Medicine, Charles University, Prague, Czech Republic
}

\section{SUMMARY}

Aim: This study seeks to assess smoking habits, attitudes and intention to quit in students of the Third Faculty of Medicine of Charles University in Prague, Czech Republic.

Methods: A cross-sectional survey designed to obtain information on smoking history, current smoking status, cessation attempts, and attitudes towards smoking among health professionals was conducted in 452 students of the first and last years of a 6-year Master's Study Programme (General Medicine) and a 3-year Bachelor's Study Programme (Public Health). An anonymous questionnaire was administered during the classes in the course of academic years 2011-12 and 2012-13.

Results: $5.7 \%$ of the Master's Study Programme students (3.3\% women and $9.0 \%$ men) and $4.8 \%$ of the Bachelor's Study Programme students reported that they are regular smokers. The share of regular smokers was almost twice as big in students of the English Curriculum of the Master's Programme (10.7\%) in comparison with the students of the Czech Curriculum (4.5\%), and more than twice as big in students of the last years of both study programmes (3.9\% in students of the 1 st year and $10.8 \%$ in students of the 6th year of the Master's Programme; $3.2 \%$ in students of the 1st year and $7.0 \%$ in students of the 3rd year of the Bachelor's Study Programme). At the time of the research, $18.9 \%$ of students of the Master's Programme and $17.1 \%$ of students of the Bachelor's Programme were occasional smokers. $5.9 \%$ of students of the Master's Programme and $19.0 \%$ of students of the Bachelor's Programme reported that they quit smoking during their studies at the medical faculty; on the contrary, $9.8 \%$ of students of the Master's Programme and $14.3 \%$ of students of the Bachelor's Programme started smoking during that time.

Conclusions: Smoking in health professionals undermines their significant role in health promotion and prevention of chronic diseases in their patients. Therefore, education at the medical faculty should focus on motivation of future health professionals towards non-smoking except providing knowledge on current research and guidance on early identification and further intervention in smokers.

Key words: tobacco use, health professions students, education, smoking cessation

Address for correspondence: D. Schneidrová, Department of Child and Youth Health, Third Faculty of Medicine, Charles University in Prague, Ruská 87, 10000 Prague 10, Czech Republic. E-mail: dagmar.schneidrova@lf3.cuni.cz

http://dx.doi.org/10.21101/cejph.a4472

\section{INTRODUCTION}

On 19 January 2015, WHO launched the "Global status report on noncommunicable diseases 2014" which provides the baseline for monitoring implementation of the "Global action plan for noncommunicable diseases (NCDS) 2013-2020”, aimed at reducing the number of premature deaths from NCDs by $25 \%$ by 2025 . Outlined in the action plan are 9 voluntary global targets that address key NCD risk factors including tobacco use, salt intake, physical inactivity, high blood pressure, and harmful use of alcohol. The target 5 calls for a $30 \%$ relative reduction in prevalence of current tobacco use in persons aged $15+$ years $(1,2)$.

Urgent government action is needed to meet global targets to reduce the burden of noncommunicable diseases, and prevent the annual toll of 16 million people dying prematurely - before the age of 70 - from heart and lung diseases, stroke, cancer and diabetes, according to a new WHO report. The report states that most premature NCD deaths are preventable. Of the 38 million lives lost to NCDs in 2012, 16 million or $42 \%$ were premature and avoidable. By investing just 1-3 US dollars per person per year, countries can dramatically reduce illness and death from NCDs. For example, in Brazil, the NCD mortality rate is dropping $1.8 \%$ per year due in part to the expansion of primary health care (1).

In 2015, every country needs to set national targets and implement cost-effective actions. As concerns tobacco, WHO recommends following very cost-effective interventions that are also high-impact and feasible for implementation even in resource-constrained settings - reduce affordability of tobacco products by increasing tobacco excise taxes; create by law completely smoke-free environments in all indoor workplaces, public places and public transport; warn people of the dangers of tobacco and tobacco smoke through effective health warnings and mass media campaigns; ban all forms of tobacco advertising, promotion and sponsorship (2). Turkey was the first country to 
implement all cost-effective, high impact measures for tobacco reduction in Europe. In 2012, the country increased the size of health-warning labels to cover $65 \%$ of the total surface area of each tobacco product. Tobacco taxes now make up $80 \%$ of the total retail price, and there is currently a total ban on tobacco advertising, promotion and sponsorship nationwide. As a result, the country saw a $13.4 \%$ relative decline in smoking rates from 2008-2012 (1).

Treatment of tobacco use and dependence is mandated in Article 14 of the World Health Organization Framework Convention on Tobacco Control (WHO FCTC) as a key component of a comprehensive tobacco control strategy. Tobacco dependence treatment is also recommended by WHO as part of a comprehensive package of essential services for prevention and control of noncommunicable diseases in primary care in accordance to the revised draft of the WHO Global Action Plan for the Prevention and Control of NCDs (2013-2020) (3).

In recent years, the Third Medical Faculty of Charles University in Prague has joined the policy of the World Health Organization (WHO) and European Union in order to prevent and reduce smoking in faculty members and students - future health professionals. The following strategies have been developed in the main areas related to academic life - education, counselling, antismoking campaign, research, and restriction of smoking at the faculty and teaching hospital (4). Besides evidence-based knowledge on health consequences of smoking and using tobacco products and public health preventive strategies, brief tobacco interventions in primary care and tobacco dependence treatment have been included in the curriculum for medical and bachelor students at the Third Faculty of Medicine, Charles University in Prague. The faculty also provides behavioural and pharmacological treatment of tobacco dependence to tobacco users among students and faculty staff. The following survey has been part of a comprehensive project aimed at prevention of tobacco use among students and faculty staff, implemented by the Third Faculty of Medicine.

\section{MATERIALS AND METHODS}

\section{Sample and Procedure}

This study was approved by the scientific board of Charles University in Prague and initiated with the support of the Institutional Development Project of the Ministry of Education, Youth and Physical Activity in 2012.

A cross-sectional survey designed to obtain information on smoking history, current smoking status, cessation attempts and attitudes towards smoking among health professionals was conducted in 452 students of the first and last years of a 6-year Master's Study Programme (General Medicine) and a 3-year Bachelor's Study Programme (Public Health) at the Third Faculty of Medicine of Charles University in Prague in the course of academic years 2011-12 and 2012-13. A self-administered anonymous questionnaire was distributed and collected during the classes by teachers engaged in the project. Each questionnaire included information outlining the aim of the research. Data were confidential, and students were informed that by completing the questionnaire they provided consent to participate in the study.
Based on the number of questionnaires returned by students the response rate was $96 \%$.

\section{Measures}

The questionnaire included general information on gender, age, study programme, year, and language of study. The specific questions related to tobacco use/smoking status, history, cessation attempts and attitudes towards smoking among health professionals were formulated as follows:

- Tobacco use/smoking status (4 items):

Ever smoking: "Have you ever smoked cigarettes or used tobacco products?" (never, occasionally in the past, regularly in the past);

Current smoking: "Currently, do you smoke cigarettes or use tobacco products?" (occasionally - less than 1 cigarette per day, regularly - at least one cigarette per day);

Use of different kinds of tobacco products: "What kind of tobacco products do you use?" (cigarettes, cigars, cigarillos, waterpipe, electronic cigarettes, chewing tobacco, snuff);

Number of cigarettes smoked per day: "How many cigarettes, cigars, etc. do you smoke a day?" (less than 1, 1-5, 6-10, 11-20, more than 20);

- Smoking history (3 items):

Age of first use of tobacco products: "At what age did you first try a cigarette or other tobacco product?" (before 10, between 11 and 14, between 15 and 18, after 18 years);

Reasons for using tobacco products: "What was the reason for starting using tobacco products?" (peers, own decision, boredom, family members smoking, others);

Family smoking: "Does anyone in your family smoke?" (both parents, one of the parents, siblings, grandparents, nobody); Smoking cessation/quitting attempts and availability of services (6 items):

Quit attempts: "Have you tried to quit smoking?" (yes - how many attempts, no);

Quitting smoking during the study: "Have you quitted smoking during the study?" (yes, no, started smoking). "If yes, was the knowledge on health risks you gained at the faculty the main reason for quitting smoking?" (yes, no, it was one of the reasons);

Smoking cessation services and availability: "Do you know about smoking cessation counselling centre at the faculty?" (yes, no) "If yes, how have you learnt about it?" (from faculty website, boards, classmates, teachers, others);

"Would you use the service if you decided to quit smoking?" (yes, no, don't know);

- Attitudes towards smoking among health professionals (1 item):

"What is your attitude towards smoking among health professionals?" (it is their personal issue, they shouldn't smoke in front of their patients, they shouldn't smoke at all, I don't know, other).

\section{Data Analysis}

The data obtained from the questionnaires were computerized using the EpiData version 3.1 program, and EpiData Analysis version 2.2.1 program was employed for the statistical analysis. 
For descriptive analyses, categorical data were expressed with contingency tables, frequencies and percentages, and quantitative data were presented as means and standard deviations. Chi-square tests for smoking variables related to gender, study programme and language of study were calculated. The difference was considered significant when $\mathrm{p}$ value was $<0.05$.

\section{RESULTS}

\section{Characteristics of the Sample}

Altogether 452 students (139 men and 313 women) took part in the survey. A sub-sample of 348 students of the Master's Study Programme included 255 students of the 1st year and 91 students of the 6th year. A sub-sample of 106 students of the Bachelor's Study Programme included 63 students of the 1st year and 43 students of the 3rd year. The average age of students of the Master's Study Programme was 21.3 years (SD 2.7), of the Bachelor's Study Programme 26 years (SD 8.3) (Table 1). A higher average age of the students of the Bachelor's Study Programme was due to the fact that the sub-sample included also students of the combined studies who are already working and use distance learning to complete their qualification even in a more adult age .

\section{Students' Smoking Status}

According to the answers obtained from the respondents, current regular smokers and users of tobacco products were $5.7 \%$ of students of the Master's Study Programme (3.3\% women and $9.0 \%$ men) and $4.8 \%$ of students of the Bachelor's Study Programme. The share of current regular smokers was almost twice as big in students of the English Curriculum of the Master's Programme $(10.7 \%, \mathrm{n}=75)$ in comparison with the students of the Czech Curriculum $(4.5 \%, \mathrm{n}=381)$. The differences between the groups were not statistically significant regarding the small size of the foreign students sub-group $\left(\chi^{2}=6.70, p=0.152\right)$. The share of current regular smokers was more than double in students of the last years of both study programmes $-3.9 \%$ of students of the 1 st year and $10.8 \%$ of students of the 6 th year of the Master's Programme $\left(\chi^{2}=9.52, p=0.049\right) ; 3.2 \%$ of students of the 1 st year and $7.0 \%$ of students of the 3rd year of the Bachelor's Programme $\left(\chi^{2}=2.72, p=0.606\right) .1 .1 \%$ of students of the Master's Programme and $6.7 \%$ of students of the Bachelor's Programme have described themselves as former regular smokers.

Table 1. Characteristics of the sample

\begin{tabular}{|c|c|c|c|c|c|}
\hline \multirow{2}{*}{} & Female & Male & Total & \multicolumn{2}{|c|}{ Age } \\
\cline { 2 - 6 } & $\mathrm{N}=\mathbf{3 1 3}(\mathbf{6 9 . 2} \%)$ & $\mathrm{N}=\mathbf{1 3 9}(\mathbf{3 0 . 8 \% )}$ & $\mathrm{N}=\mathbf{4 5 2}$ & Mean & SD \\
\hline Study programme \\
\hline Master's & $212(61.2 \%)$ & $134(38.8 \%)$ & 346 & 21.27 & 2.68 \\
\hline 1st year & $157(61.6 \%)$ & $98(38.4 \%)$ & 255 & 19.96 & 1.64 \\
\hline 6th year & $55(60.4 \%)$ & $36(39.6 \%)$ & 91 & 24.89 & 1.31 \\
\hline Bachelor's & $101(95.3 \%)$ & $5(4.7 \%)$ & 106 & 26.01 & 8.31 \\
\hline 1st year & $59(93.7 \%)$ & $4(6.4 \%)$ & 63 & 22.29 & 4.73 \\
\hline 3rd year & $42(97.7 \%)$ & $1(2.3 \%)$ & 43 & 31.60 & 9.38 \\
\hline
\end{tabular}

At the time of the survey, occasional smokers were $18.9 \%$ of students of the Master's Programme and $17.1 \%$ of students of the Bachelor's Programme. The share of occasional smokers was higher in Czech students (19.4\%) in comparison with the foreign students $\left(13.3 \%, \chi^{2}=6.70, p=0.152\right)$. The share of occasional smokers was statistically significantly lower in students of the last year of the Master's Programme (21\% of students of the $1 \mathrm{st}$ year, and $12.9 \%$ of students of the 6 th year, $\chi^{2}=9.52, p=0.049$ ), on the contrary the share of occasional smokers was higher in students of the Bachelor's Programme in the last year (16.1\% in the 1 st year and $18.6 \%$ in the 3 rd year, $\left.\chi^{2}=2.72, p=0.606\right) .13 .4 \%$ of students of the Master's Programme and $24.8 \%$ of students of the Bachelor's Programme have described themselves as former occasional smokers. $60.9 \%$ of students of the Master's Programme

Table 2. Smoking status

\begin{tabular}{|l|c|c|c|}
\hline Study programme & Female & Male & Total \\
\hline Master's & $64.3 \%$ & $54.9 \%$ & $60.9 \%$ \\
\hline Never smoked & $13.6 \%$ & $13.5 \%$ & $13.4 \%$ \\
\hline Former occasional & $0.0 \%$ & $3.0 \%$ & $1.1 \%$ \\
\hline Former regular & $18.8 \%$ & $19.5 \%$ & $18.9 \%$ \\
\hline Current occasional & $3.3 \%$ & $9.0 \%$ & $5.7 \%$ \\
\hline Current regular & & & \\
\hline Bachelor's & $46.5 \%$ & $50.0 \%$ & $46.7 \%$ \\
\hline Never smoked & $24.8 \%$ & $25.0 \%$ & $24.8 \%$ \\
\hline Former occasional & $5.9 \%$ & $25.0 \%$ & $6.7 \%$ \\
\hline Former regular & $17.8 \%$ & $0.0 \%$ & $17.1 \%$ \\
\hline Current occasional & $5.0 \%$ & $0.0 \%$ & $4.8 \%$ \\
\hline Current regular &
\end{tabular}

Significance: Study programme $p<0.01$

\begin{tabular}{|l|c|c|c|}
\hline \multicolumn{4}{|c|}{ Year of study } \\
\hline Master's & 1 st year & 6 th year & Total \\
\hline Never smoked & $61.9 \%$ & $58.1 \%$ & $60.9 \%$ \\
\hline Former occasional & $12.1 \%$ & $17.2 \%$ & $13.4 \%$ \\
\hline Former regular & $1.2 \%$ & $1.1 \%$ & $1.1 \%$ \\
\hline Current occasional & $21.0 \%$ & $12.9 \%$ & $18.9 \%$ \\
\hline Current regular & $3.9 \%$ & $10.8 \%$ & $5.7 \%$ \\
\hline Bachelor's & 1 st year & 3 rd year & \\
\hline Never smoked & $46.8 \%$ & $46.5 \%$ & $46.7 \%$ \\
\hline Former occasional & $29.0 \%$ & $18.6 \%$ & $24.8 \%$ \\
\hline Former regular & $4.8 \%$ & $9.3 \%$ & $6.7 \%$ \\
\hline Current occasional & $16.1 \%$ & $18.6 \%$ & $17.1 \%$ \\
\hline Current regular & $3.2 \%$ & $7.0 \%$ & $4.8 \%$ \\
\hline Significance: Master's p<0.05 & \multicolumn{3}{|l}{} \\
\hline \multicolumn{3}{|c|}{ Language of study } \\
\hline Master's & Czech & English & Total \\
\hline Never smoked & $57.7 \%$ & $57.3 \%$ & $57.7 \%$ \\
\hline Former occasional & $16.3 \%$ & $14.7 \%$ & $16.0 \%$ \\
\hline Former regular & $2.1 \%$ & $4.0 \%$ & $2.4 \%$ \\
\hline Current occasional & $19.4 \%$ & $13.3 \%$ & $18.4 \%$ \\
\hline Current regular & $4.5 \%$ & $10.7 \%$ & $5.5 \%$ \\
\hline
\end{tabular}


and $46.7 \%$ of students of the Bachelor's Programme reported that they never smoked $(\mathrm{p}<0.01)$ (Table 2$)$.

\section{Using Tobacco Products}

Table 3 compares kinds of utilised tobacco products and daily quantities of cigarettes smoked by students of both study programmes and both genders. In students of both study programmes, cigarette smoking was predominant (master's $-86.7 \%$, bachelor's $-100 \%$ ), second as to frequency of use was waterpipe (master's $-40.2 \%$, bachelor's $-55.0 \%$ ). In the subgroup of students of the Master's Programme, a higher share of use of smokeless tobacco $(27.3 \%$ vs. $14.3 \%)$ and cigars $(21.4 \%$ vs. $6.7 \%)$ was found in men compared to women; on the contrary in women a higher proportion of use of cigarettes ( $89.7 \%$ vs. $82.9 \%)$ and waterpipe $(52.2 \%$ vs. $25.7 \%, \mathrm{p}<0.01)$ was established. Only $12.5 \%$ of female students of the Bachelor's Programme reported experience with using electronic cigarette $(\mathrm{p}<0.01)$.

Regarding the quantity of cigarettes smoked per day - the most students reported $1-5$ cigarettes (master's $-77.8 \%$, bachelor's $-76.9 \%$ ). Only $4.0 \%$ of students of the Master's Programme

Table 3. Using tobacco products

\begin{tabular}{|c|c|c|c|}
\hline Study programme & Female & Male & Total \\
\hline \multicolumn{4}{|l|}{ Master's } \\
\hline Cigarettes & $89.7 \%$ & $82.9 \%$ & $86.7 \%$ \\
\hline Cigars & $6.7 \%$ & $21.4 \%$ & $15.9 \%$ \\
\hline Waterpipe & $52.2 \%$ & $25.7 \%$ & $40.2 \%$ \\
\hline Cigarillos & $0.0 \%$ & $12.5 \%$ & $7.5 \%$ \\
\hline Electronic cigarette & $0.0 \%$ & $0.0 \%$ & $0.0 \%$ \\
\hline Smokeless tobacco & $14.3 \%$ & $27.3 \%$ & $21.6 \%$ \\
\hline \multicolumn{4}{|l|}{ Bachelor's } \\
\hline Cigarettes & $100.0 \%$ & $100.0 \%$ & $100.0 \%$ \\
\hline Cigars & $11.1 \%$ & $0.0 \%$ & $10.0 \%$ \\
\hline Waterpipe & $57.9 \%$ & $0.0 \%$ & $55.0 \%$ \\
\hline Cigarillos & $0.0 \%$ & $0.0 \%$ & $0.0 \%$ \\
\hline Electronic cigarette & $12.5 \%$ & $0.0 \%$ & $11.1 \%$ \\
\hline Smokeless tobacco & $0.0 \%$ & $0.0 \%$ & $0.0 \%$ \\
\hline \multicolumn{4}{|c|}{ Significance: Study programme el. cig. $p<0.05$, Sex waterpipe $p<0.01$} \\
\hline \multicolumn{4}{|c|}{ Smoking quantity } \\
\hline Study programme & Female & Male & Total \\
\hline \multicolumn{4}{|l|}{ Master's } \\
\hline $1-5$ cigarettes & $85.2 \%$ & $70.5 \%$ & $77.8 \%$ \\
\hline $6-10$ cigarettes & $3.7 \%$ & $13.6 \%$ & $8.1 \%$ \\
\hline $11-20$ cigarettes & $5.6 \%$ & $13.6 \%$ & $10.1 \%$ \\
\hline$>20$ cigarettes & $5.6 \%$ & $2.3 \%$ & $4.0 \%$ \\
\hline \multicolumn{4}{|l|}{ Bachelor's } \\
\hline $1-5$ cigarettes & $80.0 \%$ & $0.0 \%$ & $76.9 \%$ \\
\hline $6-10$ cigarettes & $12.0 \%$ & $100.0 \%$ & $15.4 \%$ \\
\hline $11-20$ cigarettes & $8.0 \%$ & $0.0 \%$ & $7 . \%$ \\
\hline$>20$ cigarettes & $0.0 \%$ & $0.0 \%$ & $0.0 \%$ \\
\hline
\end{tabular}

(5.6\% women and $2.3 \%$ men) reported more than 20 cigarettes smoked per day.

\section{Smoking History}

Table 4 states age and reasons for starting using tobacco products in students of both genders and both study programmes, and smoking in their families. The most students started using tobacco products between 11 and 14 years of age (master's $30.9 \%$, bachelor's $-38.9 \%$ ) and between 15 and 18 years of age (master's $-33.1 \%$, bachelor's $-32.6 \%$ ). Only $7.2 \%$ of students of the Master's Study Programme and $8.4 \%$ of students of the Bachelor's Study Programme started smoking after their 18th year. Female students of the Master's Study Programme reported the age of commencement of smoking between 11 and 14 years to a higher degree than male students $(32.3 \%$ women vs. $28.2 \%$ men); on the contrary men more frequently reported a later age of commencement of smoking between 15 and 18 years $(36.3 \%$ men vs. $31.3 \%$ women). The smokers' main reasons for smoking initiation were peer pressure, own decision, smoking in the family. As for reasons for smoking initiation, the differences between study programmes and genders were statistically significant $(\mathrm{p}<0.05)$. As for family smoking, students reported most often smoking of one parent (master's $-21.7 \%$, bachelor's $-21.0 \%$ ), both parents (master's $-6.9 \%$, bachelor's $-18.1 \%$ ), grandparents (master's $-9.5 \%$, bachelor's $-7.6 \%$ ), and siblings (master's $3.2 \%$, bachelor's $-6.7 \%$ ).

\section{Smoking Cessation}

As for quitting attempts and readiness, $18.4 \%$ of current smokers from the Master's Study Programme and 26.1\% of smokers from the Bachelor's Study Programme had tried to quit smoking at least once in the past. $47.4 \%$ of current smokers from the Master's Study Programme (56\% females, 36.4\% males ) and $47.8 \%$ of smokers from the Bachelor's Study Programme expressed their intention to quit smoking in the future. $34.2 \%$ of current smokers from the Master's Study Programme (26.8\% females, $45.5 \%$ males) and $21.7 \%$ of smokers from the Bachelor's Study Programme reported that they are not ready to quit smoking .

$5.9 \%$ of students of the Master's Study Programme and 19\% of students of the Bachelor's Study Programme said that they quit smoking during their studies at the Third Medical Faculty; on the contrary, $9.8 \%$ of students of the Master's Study Programme and $14.3 \%$ of students of the Bachelor's Study Programme started smoking. Only $24.1 \%$ of students of the Master's Study Programme reported knowledge about health risks of smoking acquired during their studies as the main reason for their smoking cessation, and $10.3 \%$ of students of the Master's Study Programme and $44.4 \%$ of students of the Bachelor's Study Programme reported the acquired knowledge as one of the reasons to quit smoking. The differences in answers between students of both study programmes and genders were not statistically significant.

Only $26.4 \%$ of students of the Master's Study Programme and $75.9 \%$ of students of the Bachelor's Study Programme reported that they knew about the existence of the Smoking Cessation Counselling Centre at the Faculty $\left(\chi^{2}=21.80, p<0.001\right)$. Women 
Table 4. Smoking history

\begin{tabular}{|c|c|c|c|}
\hline \multicolumn{4}{|c|}{ Age of first use of tobacco products } \\
\hline Study programme & Female & Male & Total \\
\hline \multicolumn{4}{|l|}{ Master's } \\
\hline Never & $25.5 \%$ & $22.6 \%$ & $24.1 \%$ \\
\hline$\leq 10$ years & $3.6 \%$ & $6.5 \%$ & $4.7 \%$ \\
\hline $11-14$ years & $32.3 \%$ & $28.2 \%$ & $30.9 \%$ \\
\hline $15-18$ years & $31.3 \%$ & $36.3 \%$ & $33.1 \%$ \\
\hline$>18$ years & $7.3 \%$ & $6.5 \%$ & $7.2 \%$ \\
\hline \multicolumn{4}{|l|}{ Bachelor's } \\
\hline Never & $13.2 \%$ & $0.0 \%$ & $12.6 \%$ \\
\hline$\leq 10$ years & $6.6 \%$ & $25.0 \%$ & $7.4 \%$ \\
\hline $11-14$ years & $39.6 \%$ & $25.0 \%$ & $38.9 \%$ \\
\hline $15-18$ years & $33.0 \%$ & $25.0 \%$ & $32.6 \%$ \\
\hline$>18$ years & $7.7 \%$ & $25.0 \%$ & $8.4 \%$ \\
\hline \multicolumn{4}{|c|}{ Reasons for using tobacco products } \\
\hline Study programme & Female & Male & Total \\
\hline \multicolumn{4}{|l|}{ Master's } \\
\hline Peers & $69.4 \%$ & $51.3 \%$ & $61.7 \%$ \\
\hline Own decision & $18.5 \%$ & $23.1 \%$ & $20.7 \%$ \\
\hline Boredom & $1.9 \%$ & $7.7 \%$ & $4.3 \%$ \\
\hline Family smoking & $0.0 \%$ & $3.8 \%$ & $1.6 \%$ \\
\hline Other & $10.2 \%$ & $14.1 \%$ & $11.7 \%$ \\
\hline \multicolumn{4}{|l|}{ Bachelor's } \\
\hline Peers & $63.8 \%$ & $100.0 \%$ & $65.8 \%$ \\
\hline Own decision & $11.6 \%$ & $0.0 \%$ & $11.0 \%$ \\
\hline Boredom & $0.0 \%$ & $0.0 \%$ & $0.0 \%$ \\
\hline Family smoking & $7.2 \%$ & $0.0 \%$ & $6.8 \%$ \\
\hline Other & $17.4 \%$ & $0.0 \%$ & $16.4 \%$ \\
\hline \multicolumn{4}{|c|}{ Significance: Study programme $p<0.05, \operatorname{sex} p<0.05$} \\
\hline \multicolumn{4}{|c|}{ Family smoking } \\
\hline Study programme & Female & Male & Total \\
\hline \multicolumn{4}{|l|}{ Master's } \\
\hline Both parents & $9.0 \%$ & $3.8 \%$ & $6.9 \%$ \\
\hline One parent & $21.4 \%$ & $22.9 \%$ & $21.7 \%$ \\
\hline Siblings & $4.3 \%$ & $1.5 \%$ & $3.2 \%$ \\
\hline Grandparents & $6.7 \%$ & $14.5 \%$ & $9.5 \%$ \\
\hline Nobody & $58.6 \%$ & $57.3 \%$ & $58.7 \%$ \\
\hline \multicolumn{4}{|l|}{ Bachelor's } \\
\hline Both parents & $19.0 \%$ & $0.0 \%$ & $18.1 \%$ \\
\hline One parent & $22.0 \%$ & $0.0 \%$ & $21.0 \%$ \\
\hline Siblings & $7.0 \%$ & $0.0 \%$ & $6.7 \%$ \\
\hline Grandparents & $8.0 \%$ & $0.0 \%$ & $7.6 \%$ \\
\hline Nobody & $44.0 \%$ & $100.0 \%$ & $46.7 \%$ \\
\hline Significance: Study $\mathrm{p}$ & $0.01, \operatorname{sex}$ & & \\
\hline
\end{tabular}

Table 5. Smoking cessation

\begin{tabular}{|c|c|c|c|}
\hline \multicolumn{4}{|c|}{ Quitting attempts, intention, readiness } \\
\hline Study programme & Female & Male & Total \\
\hline \multicolumn{4}{|l|}{ Master's } \\
\hline Ever tried & $17.1 \%$ & $18.2 \%$ & $18.4 \%$ \\
\hline Intention to quit in future & $56.1 \%$ & $36.4 \%$ & $47.4 \%$ \\
\hline Not ready to quit & $26.8 \%$ & $45.5 \%$ & $34.2 \%$ \\
\hline \multicolumn{4}{|l|}{ Bachelor's } \\
\hline Ever tried & $27.3 \%$ & $0.0 \%$ & $26.1 \%$ \\
\hline Intention to quit in future & $50.0 \%$ & $0.0 \%$ & $47.8 \%$ \\
\hline Not ready to quit & $22.7 \%$ & $0.0 \%$ & $21.7 \%$ \\
\hline \multicolumn{4}{|c|}{ Have quitted during the study } \\
\hline Study programme & Female & Male & Total \\
\hline \multicolumn{4}{|l|}{ Master's } \\
\hline Yes & $4.5 \%$ & $7.4 \%$ & $5.9 \%$ \\
\hline No & $81.8 \%$ & $85.2 \%$ & $84.3 \%$ \\
\hline No, started smoking & $13.6 \%$ & $7.4 \%$ & $9.8 \%$ \\
\hline \multicolumn{4}{|l|}{ Bachelor's } \\
\hline Yes & $21.1 \%$ & $0.0 \%$ & $19.0 \%$ \\
\hline No & $63.2 \%$ & $100.0 \%$ & $66.7 \%$ \\
\hline No, started smoking & $15.8 \%$ & $0.0 \%$ & $14.3 \%$ \\
\hline \multicolumn{4}{|c|}{ Reason for quitting smoking } \\
\hline Study programme & Female & Male & Total \\
\hline \multicolumn{4}{|l|}{ Master's } \\
\hline Knowledge on health & $16.7 \%$ & $26.7 \%$ & $24.1 \%$ \\
\hline One of reasons & $8.3 \%$ & $13.3 \%$ & $10.3 \%$ \\
\hline No & $75.0 \%$ & $60.0 \%$ & $65.5 \%$ \\
\hline \multicolumn{4}{|l|}{ Bachelor's } \\
\hline Knowledge on health & $0.0 \%$ & $0.0 \%$ & $0.0 \%$ \\
\hline One of reasons & $50.0 \%$ & $0.0 \%$ & $44.4 \%$ \\
\hline No & $50.0 \%$ & $100.0 \%$ & $55.6 \%$ \\
\hline
\end{tabular}

to a higher degree than men stated they knew about the existence of the counselling centre $\left(50.6 \%\right.$ vs. $18.4 \%, \chi^{2}=12.09$, $\mathrm{p}<0.001) .49 \%$ of students who knew about the existence of the counselling centre had learned about it from faculty notice boards, $33.3 \%$ from teachers, $17.6 \%$ from a website and $9.8 \%$ from classmates. Only $19.6 \%$ of students reported that they would use the services of the counselling centre if they decided to quit smoking (Table 5).

\section{Opinion about Smoking in Health Professionals}

Table 6 points out the differences in frequencies of answers to the question concerning opinion on smoking in medical staff among students of both study programmes and between genders. However, the differences were not statistically significant. The future medical doctors, students of the Master's Programme, to a higher degree $(28.1 \%)$ answered that smoking was a personal affair of health professionals, in comparison with the students of the Bachelor's Programme on Public Health (17.6\%). Similarly, 
Table 6. Opinion about smoking in health professionals

\begin{tabular}{|c|c|c|c|}
\hline Study programme & Female & Male & Total \\
\hline \multicolumn{4}{|l|}{ Master's } \\
\hline Personal issue & $23.5 \%$ & $33.7 \%$ & $28.1 \%$ \\
\hline $\begin{array}{l}\text { Shouldn't smoke in front of } \\
\text { patients }\end{array}$ & $31.6 \%$ & $27.7 \%$ & $29.9 \%$ \\
\hline Shouldn't smoke & $39.0 \%$ & $32.5 \%$ & $36.2 \%$ \\
\hline Don't know & $5.9 \%$ & $6.0 \%$ & $5.8 \%$ \\
\hline \multicolumn{4}{|l|}{ Bachelor's } \\
\hline Personal issue & $17.5 \%$ & $20.0 \%$ & $17.6 \%$ \\
\hline $\begin{array}{l}\text { Shouldn't smoke in front of } \\
\text { patients }\end{array}$ & $37.5 \%$ & $20.0 \%$ & $36.5 \%$ \\
\hline Shouldn't smoke & $43.8 \%$ & $20.0 \%$ & $42.4 \%$ \\
\hline Don't know & $1.3 \%$ & $40.0 \%$ & $3.5 \%$ \\
\hline
\end{tabular}

men from the subgroup of the future medical doctors claimed to a higher degree than women that smoking was a personal affair $(33.7 \%$ vs. $23.5 \%)$. Moreover, the future doctors to a lower degree than the future bachelors answered that a health professional should never smoke in front of patients $(29.9 \%$ vs. $36.5 \%)$ and that a health professional should not smoke at all (36.2\% vs. $42.4 \%)$. Similarly, men from the subgroup of the future doctors declared to a lower degree than women that a health professional should never smoke in front of patients $(27.7 \%$ vs. $31.6 \%)$, and that a health professional should not smoke at all (32.5\% vs. $39.0 \%)$.

\section{DISCUSSION}

This study examined current smoking status, smoking history, cessation attempts and attitudes towards smoking in health professionals among students of the Third Faculty of Medicine of Charles University in Prague. There were some limitations to be considered. The study was designed as a cross-sectional, the sample was limited to a specific group of future health professionals. The self-administered questionnaire was anonymous, however, distributed and collected by teachers during the classes, therefore a potential bias is related to self-reported smoking behaviour and attitudes.

The prevalence of current smoking among students in our sample $(23.3 \%$, i.e. $5.3 \%$ of current regular/daily smokers and $18 \%$ of current occasional smokers) was lower compared to the Czech population group aged 15-24 years with the highest prevalence among age population groups $(33.6 \%$, i.e. $28.2 \%$ smoking at least 1 cigarette per day, 5.4\% smoking less than 1 cigarette per day) (4-6).

The prevalence of current smoking among students in our sample was also lower compared to the sample of Czech students aged 14-24 years enrolled into the CINDI Health Monitor Study in $2005(31.7 \%$, i.e. $14.3 \%$ of current daily smokers, $17.4 \%$ of current occasional smokers) (7); the sample of students across 7 universities in Gaza, Palestine (31.1\% of current smokers, 21\% of current regular smokers, $10 \%$ of current occasional smokers), students of physical education and sports school in Turkey $(25 \%$ of current smokers), university students in Jordan (29\% smoked cigarettes in past 30 days), medical students in Syria (27\% smok- ing prevalence), and higher than in students of engineering in Iran ( $21.5 \%$ smoked during the past 30 days), and university students in Egypt ( $9 \%$ smoked during the 3 months before the survey) (8). As for gender, we had more current regular male smokers $(9.0 \%)$ than female ones (3.3\%) among medical students. Similarly, in Syria, male students had 3 times higher prevalence of smoking than females (9). However, the prevalence of occasional smokers was similar in males (19.5\%) and females $(18.8 \%)$ in our subsample of medical students. Arab countries show significantly higher rates of cigarette smoking among males, due to the social stigma of women's smoking (smoking is considered inappropriate behaviour for women) (8). Gender differences could be culture specific, as the ratio of smoking is high among men in Eastern societies but high among women in Western societies when compared to Eastern societies (10).

We also compared the prevalence of current smoking among students in our sample $(23.3 \%)$ with the results of surveys of health professions students. The prevalence of current smoking was similar in Hungarian students of dentistry (20.3\% in 2011) (11) and lower in the sample of Czech medical students from Masaryk University in Brno. Only $5.5 \%$ of the 6 th year medical students reported themselves as smokers, $2.8 \%$ of students smoked regularly during the last month in 2011-2012 (12). The Global Health Professions Student Survey (GHPSS) is part of the Global Tobacco Surveillance System developed by WHO and the Office on Smoking and Health (OSH) of the United States Centers for Disease Control and Prevention (CDC). The GHPSS is a school-based survey of the 3rd year students pursuing degrees in dentistry, medicine, pharmacy, and nursing. The 2011 study in CR included 1,671 students from 28 schools. The sample was selected from all medical, dental, nursing and pharmacy schools in the Czech Republic. Findings show that nursing students had the highest prevalence $(32.2 \%)$ of current cigarette smoking. The prevalence of current cigarette smoking was lower in students of pharmacy (22.4\%), dentistry (21.5\%), and the lowest among medical students (19.7\%). The prevalence of other tobacco use than cigarettes (chewing tobacco, cigarillos, cigars, pipes) among medical students was 7.5\%, 10.3\% among dental students, $8.2 \%$ among nursing students, and $8.2 \%$ among pharmacy students (13).

As the most frequently used tobacco product the smokers in our sample have reported a cigarette $(86.7 \%$ medical students, $100 \%$ bachelors) which corresponds with the use in the Czech population. The share of other tobacco products is significantly lower in comparison with cigarette smoking $(0.6 \%$ pipe, $2.1 \%$ cigars, $2.5 \%$ waterpipe). Both men and women in CR smoke most often 10-14 cigarettes a day $(30.5 \%$ and $28.5 \%$, respectively), the youngest age groups smoke up to 10 cigarettes a day (52.7\%) (6). Most smokers in our sample reported smoking 1-5 cigarettes $(77.8 \%$ of master's students, $76.9 \%$ of bachelor's students). Only $4.0 \%$ of master's students reported more than 20 cigarettes smoked per day, which will probably represent the proportion of students who may be nicotine dependent and need help in smoking cessation. The second place as for frequency of use has been taken by the waterpipe. $40.2 \%$ of smokers - medical students - reported using waterpipe. For comparison, $80 \%$ of medical students from Brno reported single attempts with smoking waterpipe (12). From the survey in population of the Czech Republic it follows that waterpipe smoking is quite unequivocally related to age - this way 
of smoking is preferred particularly by the youngest age groups; the prevalence of waterpipe smoking diminishes with age $(5,6)$.

Students in our sample started smoking mostly before entering university. 9.8\% of students of the Master's Study Programme and $14.3 \%$ of students of the Bachelor's Study Programme started smoking as late as after entering university. Students of the Medical Faculty of Masaryk University Brno dated their first smoker's attempts most often to the age between 11 and 15 years $(31 \%)$ or 16 and 17 years $(23 \%) .9 \%$ of students have made their first attempts to smoke during their studies at the university (12). Why do health professions students start smoking at university? Stress related to demanding study requirements and examinations might be one of important contributing factors. Hungarian authors found a strong correlation between stress, anxiety and smoking in medical and dental students (11).

Approximately $30 \%$ of current smokers in the Czech Republic have tried to quit smoking during the last year $(29.6 \%$ of men, $33.3 \%$ of women). The most frequent were attempts in the youngest smokers (15-24 years), in $40.4 \%$ of cases $(4,5)$. As for quitting attempts and readiness in our sample, $18.4 \%$ of current smokers from the Master's Study Programme and 26.1\% of smokers from the Bachelor's Study Programme had tried to quit smoking at least once in the past. 5.9\% of students of the Master's Study Programme and $19.0 \%$ of students of the Bachelor's Study Programme reported that they quit smoking during their studies at the Third Faculty of Medicine. Approximately half of current smokers expressed their intention to quit smoking in the future.

Educational institutions training health professions students should help their students quit using tobacco by providing encouragement and information to students who are considering quitting and provide assistance to students who are motivated to quit (13). Individual interventions, such as behavioural counselling and pharmacological therapy, are likely to induce individual cessation efforts and significantly increase the probability of long term smoking cessation in adults. On the other hand, smoking cessation in young people requires specific approach because pharmacological and strictly behavioural measures do not seem to be so efficient. It is important to be aware of a different pattern of smoking habit among young people: a majority of them are not regular smokers and hopefully not yet dependent on nicotine (16). At the beginning of the academic year, students of the Third Faculty of Medicine are informed on services of the Students Counselling Centre affiliated to the Department of Child and Youth Health, including the smoking cessation consultancy, via the Students Department, bulletins and boards at the faculty. The consultancy includes the first contact with a client, motivational dialogue and behavioural counselling and support in the process of quitting smoking $(14,15)$. Clients who need pharmacological treatment are referred to the specialized Centre for the Treatment of Tobacco Dependence at the Clinic of Occupational and Travel Medicine of Vinohrady Teaching Hospital (16).

We were interested in the attitude of students towards smoking in health professionals. Only $29.9 \%$ of future doctors in our sample answered that a health professional should not smoke in front of patients, and $36.2 \%$ stated that a health professional should not smoke at all. In contrast, $82 \%$ of students from the GHPSS survey in CR thought that health professionals should serve as role models for their patients and advise them not to smoke. However, only $53 \%$ of them really felt to be such role models.
Six in ten students assumed that health professionals who smoke are less likely to advise patients to stop smoking (13). Although in Anglo-Saxon countries less then 5\% of doctors and about $10 \%$ of nurses smoke, in some other countries the prevalence of smoking health professionals is extremely high, e.g. in Italy the proportion of smokers among health professionals is twice as high as in the population at large (44\% vs. $21 \%$ ) (17). In the Czech Republic, about $16 \%$ of doctors smoke. Smoking among nurses has dropped by $10 \%$ during the last 20 years, however, it is still considerably more frequent as compared to the female population (40\%, which is almost double than in women in population at large) (18).

Currently, it is exceptional rather than routine practice that smoking patients are motivated by their doctors to quit smoking. The reasons of this passive attitude most often mentioned by the doctors are that the smokers do not want to quit smoking. Doctors do not consider the intervention for smoking cessation to be their priority, counselling to smokers is time consuming, patients perceive the recommendations as annoying. These arguments testify to the fact that a low degree of attention is paid to the education concerning the issue of smoking in pregradual students' curriculum (19).

The promising impact of pregradual medical curriculum developed at the Medical Faculty at Masaryk University Brno in the 1990s was followed up in research studies - the majority of graduate students accept non-smoking as an obvious part of life style and understand the specific role of health professionals in the reduction of the smoking epidemic. During their pregradual studies, more than one third of students have obtained practical skills in order to advice and support patients with smoking cessation. There are still some reserves in noncompliance with the smoking ban at the Medical Faculty premises and in the training of practical skills in counselling of students (12).

In recent years, topics related to smoking are regularly included into curriculum of medical and bachelor studies at our faculty. The Department of Child and Youth Health presents the topics on smoking prevalence, health consequences and epidemiology of smoking related health diseases, prevention and treatment in the subject called Hygiene, Epidemiology and Preventive Medicine to the 3rd year medical students and to the 3rd year bachelor students in the subject called Health Promotion. The 5th year medical students are instructed on the WHO early identification and brief intervention strategies related to tobacco, alcohol and other addictive substances to be applied in primary health care (20). The Department of Pharmacology presents pharmacological aspects of tobacco dependence and treatment in the course on Mental Disorders in the 3rd year to medical students. The department also presents an optional course on prevention and treatment of drug dependences. Apart from the instruction based on current research, in the practical part students are invited to work on proposal of a poster for campaign against smoking in students and health professionals. Thus students contributed with their pieces of art to the faculty art contest and exhibition related to the WHO antismoking campaign on May 31 in the last four years.

\section{CONCLUSIONS}

Health professionals have been found to play an important role in prevention and cessation of tobacco use among their patients. 
Therefore, smoking in health professionals undermines their significant role in health promotion and prevention of chronic diseases in their patients. Educational institutions should discourage tobacco use among health professions students and implement programmes that strengthen students' awareness about their role as models for their patients and public, to enhance their responsibility to advice all patients to quit smoking, and train health professions students in effective smoking cessation counselling techniques. The Third Faculty of Medicine of Charles University provides knowledge on current research on health impact of tobacco use and guidance on early identification and further intervention in smokers. However, results on smoking patterns and attitudes in our students indicate that besides required knowledge the professional responsibility and motivation towards non-smoking should be encouraged in future health professionals.

\section{Acknowledgements}

This study was supported by the Institutional Development Projects of the Ministry of Education, Youth and Physical Activity in 2012, 2013, 2014 and the PRVOUK P02 and P34 Programmes of the Charles University in Prague in 2014.

\section{Conflict of Interests}

None declared

\section{REFERENCES}

1. World Health Organization. Media centre. News releases [Internet] Geneva: WHO; 19 January 2015 [cited 2015 Feb 24]. Noncommunicable diseases prematurely take 16 million lives annually, WHO urges more action. Available from: http://www.who.int/mediacentre/news/ releases/2015/noncommunicable-diseases/en/.

2. Global status report on noncommunicable diseases 2014. Geneva: World Health Organization; 2014.

3. Strengthening health systems for treating tobacco dependence in primary care. Building capacity for tobacco control: training package. Geneva: World Health Organization; 2013.

4. Schneidrová D, Kopřivová Herotová T, Šustková M. Smoking prevention activities at the Third Faculty of Medicine of Charles University in Prague, Czech Republic. Cent Eur J Public Health. 2012 Mar;20(1):67.

5. Kodl M, editor. Report on health of inhabitants of the Czech Republic. Prague: Ministry of Health, Czech Republic; 2014. (In Czech.)

6. Sovinová H, Sadílek P, Csémy L. Development of smoking prevalence in an adult population in the Czech Republic, opinions and attitudes of Czech citizens in relation to smoking (1997-2011). Research Report [Internet]. Prague: National Institute of Public Health; 2012 [cited 2013 Dec 20]. Available from: http://www.szu.cz/uploads/documents/czzp/ zavislosti/koureni/zprava-kuractvi-2011.pdf. (In Czech.)

7. Csémy L, Sovinová H, Sadílek P. Tobacco use in the Czech Republic 2013 [Internet]. Prague: National Institute of Public Health; 2014 [cited 2014 May 26]. Available from: http://www.szu.cz/uploads/documents/czzp/ CPVZ_aktualne/Tabak_Sovinova/UzivaniTabaku2013.pdf. (In Czech.)

8. World Health Organization. Tobacco Free Initiative (TFI). Tobacco control country profiles [Internet]. Geneva: WHO; 2015 [cited 2015 Mar 2].
WHO Report on the Global Tobacco Epidemic, Country profile Czech Republic, 2013. Available from: http://who.int/tobacco/surveillance/ policy/country profile/en/.

9. Skálová L, Komárek L, Procházka B, Říhová M. CINDI Health Monitor at Students [Internet]. Prague: National Institute of Public Health; 2008 [cited 2013 Dec 20]. Available from: http://www.szu.cz/uploads/documents/czzp/CINDI/CINDI_stud_angl.pdf. (In Czech.)

10. Abu Shomar RT, Lubbad IK, El Ansari W, Al-Khatib IA, Alharazin HJ. Smoking, awareness of smoking-associated health risks, and knowledge of national tobacco legislation in Gaza, Palestine. Cent Eur J Public Health. 2014 Jun;22(2):80-9.

11. Al-Kubaisy W, Abdullah NN, Al-Nuaimy H, Halawany G, Kurdy S Epidemiological study on tobacco smoking among university students in Damascus, Syrian Arab Republic. East Mediterr Health J. 2012 Jul;18(7):723-7.

12. Warren CW, Sinha DN, Lee J, Lea V, Jones NR. Tobacco use, exposure to secondhand smoke, and training on cessation counselling among nursing students: cross-country data from the Global Health Professions Student Survey (GHPSS), 2005-2009. Int J Environ Res Public Health. 2009 Oct;6(10):2534-49.

13. Antal M, Forster A, Zalai Z, Barabás K, Ramseier Ch, Nagy K. Attitudes of Hungarian dental professionals to tobacco use and cessation. Cent Eur J Public Health. 2012 Mar;20(1):45-9.

14. Šikolová V, Sovinová H, Hrubá D. Global Health Professions Student Survey (GHPSS): results in students at Medical Faculty, Masaryk University, Brno. Hygiena. 2013;58(3):106-10. (In Czech.)

15. Sovinová H. Czech Republic 2011 Country Report. Global Health Professions Student Survey (GHPSS) [Internet]. Prague: National Institute of Public Health; 2013 [cited 2014 May 26]. Available from: http://www. szu.cz/uploads/documents/czzp/zavislosti/koureni/2013/GHPSS Country_Report_CR.pdf. (In Czech.)

16. Padjen I, Dabić M, Glivetić T, Biloglav Z, Biočina-Lukenda D, Lukenda J. The analysis of tobacco consumption in Croatia - are we successfully facing the epidemic? Cent Eur J Public Health. 2012 Mar;20(1):5-10.

17. Society for Treatment of Tobacco Dependence [Internet]. Prague: SLZT 2015 [cited 2015 Mar 31]. Centre for Tobacco-Dependent, 3rd Medical Department, First Faculty of Medicine, Charles University, and the General University Hospital in Prague. Intervention structure. Available from: http://www.slzt.cz/intervention-structure/. (In Czech.)

18. Malá K, Felbrová V, Kulovaná S, Králíková E, Štěpánková L. Recommended guidelines: treatment of tobacco dependence [Internet]. Prague: Czech Association for Nurses; 2010 [cited 2014 May 10]. Available from: http://www.slzt.cz/dokumenty/DoporCAS.pdf. (In Czech.)

19. Hrubá D. Pharmacotherapy in smoking cessation: pharmacological principles and clinical practice. Hygiena. 2014;59(1):9. (In Czech.)

20. Cattaruzza MS, West R. Why do doctors and medical students smoke when they must know how harmful it is? Eur J Public Health. 2013 Apr;23(2):188-9.

21. Králíková E, et al. Tobacco dependence: epidemiology, prevention and treatment. 1st edition. Břeclav: Adamira; 2013. (In Czech.)

22. La Torre G. Is there an emergency of tobacco smoking among health professionals in the European region? Eur J Public Health. 2013 Apr;23(2):189-90. (In Czech.)

23. Štěpánková L. International guidelines for smoking cessation in primary health care: IPCRG (International Primary Care Respiratory Group). Postgradual Med. 2008;10(Suppl):28-50. (In Czech.) 